\title{
7 TAHAP PENELITIAN
}

oleh: Citra Kurniawan

Email: airakurniawan@gmail.com

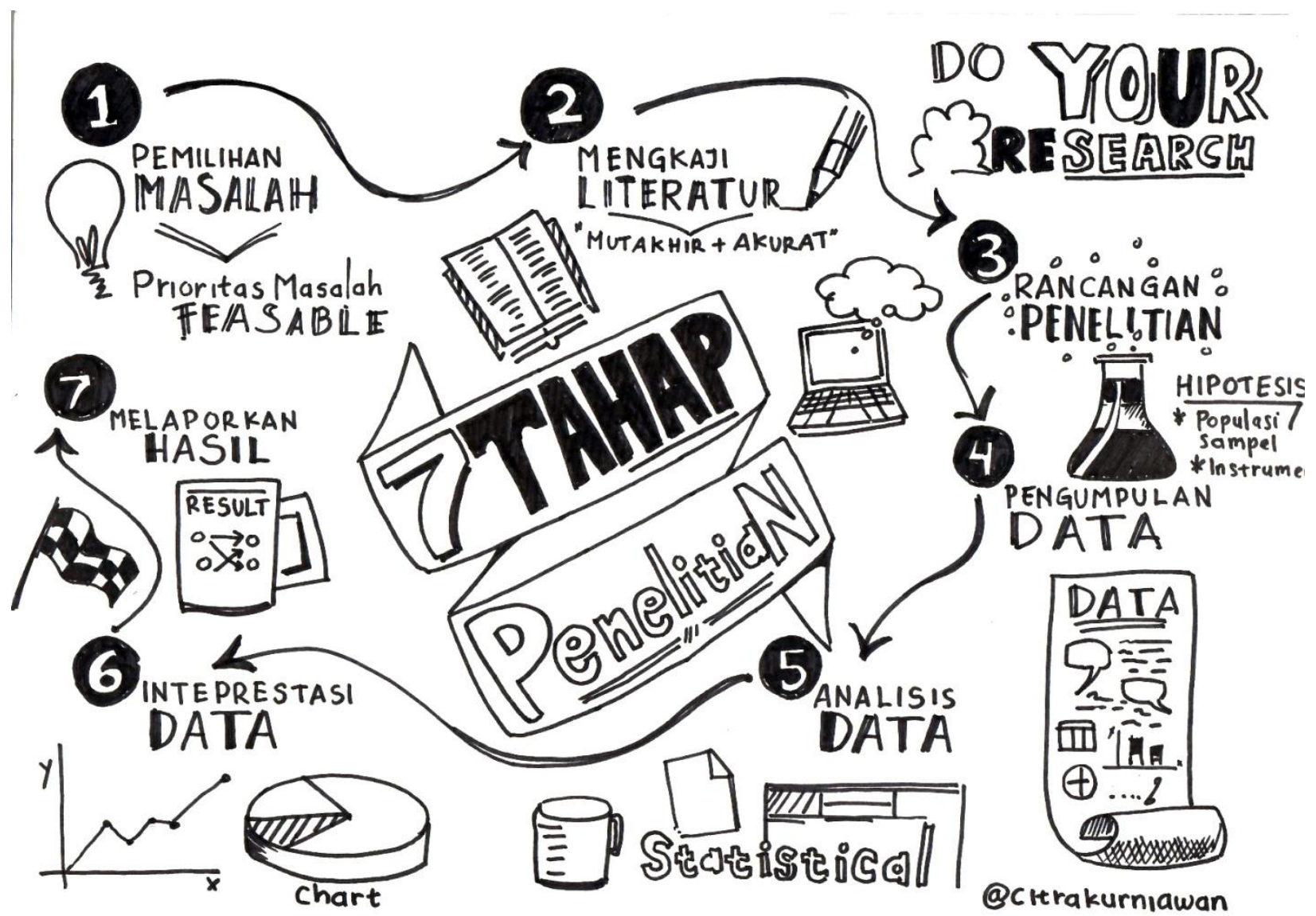

Sebuah penelitian selalu diawali dengan proses identifikasi masalah, dimana masalah yang menjadi concern penelitian diharapkan dapat diselesaikan dengan metode/cara yang akan diterapkan pada penelitian. Masalah yang akan diselesaikan harus bersifat feasible atau layak. Sifat feasible ini wajib dimiliki oleh sebuah masalah. Pada tahap selanjutnya adalah melakukan kajian literatur terhadap materi / bahasan yang mendukung terhadap metode pemecahan masalah dalam penelitian. Kajian literatur bertujuan untuk mengembangkan pemahaman dan wawasan secara menyeluruh terhadap penelitian penelitian yang telah dilakukan dan teori yang telah ada sebelumnya. Tahap yang ketiga adalah menyusun sebuah rancangan penelitian. Rancangan penelitian terdiri dari penyusunan hipotesis, penentuan subjek penelitian dan penentuan instrumen penelitian. Proses selanjutnya adalah proses pengumpulan data. Proses pengumpulan data dilakukan dengan menggunakan instrumen yang telah ditentukan, dimana instrumen penelitian tersebut dapat mendukung pencapaian tujuan penelitian. Analisis data dilakukan sebagai upaya untuk menjelaskan / melakukan deskripsi terhadap data yang telah diolah sebelumnya. Hasil analisis daya kemudian dilakukan interpretasi data dengan tujuan untuk mencari jawaban dari hipotesis masalah yang telah diajukan. Pada Bagian akhir, kesimpulan penelitian dikemukakan sebagai jawaban dari masalah yang telah diajukan sebelumnya. 